\title{
27. PALEOCENE AND EARLY EOCENE PLANKTONIC FORAMINIFERA LEG 32, DEEP SEA DRILLING PROJECT
}

\author{
Hanspeter Luterbacher, Esso Production Research-European, 33321 Bègles, France
}

\section{INTRODUCTION}

During Leg 32 in the northwestern Pacific, Paleocene and early Eocene planktonic foraminifera were recovered at three sites (Figure 1): Site 305 (Shatsky Rise), Site 308 (Kōko Seamount of the Emperor Seamount chain), and Site 313 (northeastern MidPacific Mountains). However, none of the three sequences cored contains a complete Paleocene-early Eocene sequence because of poor recovery, unconformities, and dissolution of planktonic foraminifera.

The Paleocene-Eocene planktonic foraminiferal zonation used in this chapter is discussed in Stainforth et al. (in press). The same paper also contains a description of most of the species cited hereafter as well as an extensive bibliography. Therefore, reference should be made mainly to Stainforth (et al., in press) for more detailed stratigraphic and taxonomic discussions.

\section{SITE 305-SHATSKY RISE}

\section{(lat $32^{\circ} 00.13^{\prime} \mathrm{N}$, long $157^{\circ} 51.00^{\prime} \mathrm{E}$, water depth $2903 \mathrm{~m}$ )}

The Cretaceous-Tertiary boundary is situated between Cores 14 and 15. Both cores were unconsolidated, water-saturated and mechanically disturbed; in addition, recovery was incomplete. Detailed sampling is therefore somewhat illusionary and the section recovered is unfit for a study of the Cretaceous-Tertiary transition. The top of Core 15 is Maestrichtian in age.

The bulk of the core-catcher sample from Core 14 consists of tan coccolith ooze which contains a few white chalky lumps. A sample from these lumps was washed separately and contained a very rich and well-preserved microfauna characteristic for the early Paleocene (Globorotalia trinidadensis Zone) mixed with specimens of the middle Paleocene (Globorotalia uncinata and Globorotalia angulata Zones). Small heterohelicids are very abundant (for distribution of characteristic species, abundance and preservation of microfaunas, and location of samples, see Figure 2). A sample from the tan ooze, which represents most of the core-catcher sample of Core 14, is dated as middle Paleocene (Globorotalia pusilla pusilla Zone) based on the occurrence of the marker species. Benthonic foraminifera are extremely rare and represented by a few lagenids, Aragonia sp., and Eponides sp.

Samples taken from Sections 5 and 4 of Core 14 are also of middle Paleocene age (Globorotalia pusilla pusilla Zone). Moderate to strong dissolution of the tests of planktonic foraminifera occurs in the upper two samples from this interval. Most of the tests of the larger specimens are etched and incomplete. Accordingly, the percentage of benthonic foraminifera is higher ( $\mathrm{Ara}$ gonia sp. sp., lagenids, Eponides sp., Osangularia sp.,
Buliminella sp.). Sample $14-4,20-22 \mathrm{~cm}$, contains a few fish teeth.

The three samples taken in Sections 3 to 1 of Core 14 and the core-catcher sample of Core 13 contain Globorotalia pseudomenardii and are therefore referred to that homonymous zone of the late Paleocene. Sample 14-3, $42-44 \mathrm{~cm}$, is relatively poor with indications of dissolution, whereas the other three samples are very rich and well preserved with only weak indications of dissolution of the planktonic foraminiferal tests. Globigerina mckannai $(=$ Acarinina subsphaerica $)$ is very abundant in Sample 14-1, 135-138 cm, and in the core-catcher sample of Core 13.

The planktonic foraminiferal assemblages from Sections 6 to 1 of Core 13 are typical for the late Paleocene (Globorotalia velascoensis Zone). The washed residues of the samples taken in Sections 6, 5, 4, and 1 consist almost exclusively of planktonic foraminifera with only weak to moderate dissolution of the tests. However, the two samples from Sections 3 to 2 show strong indications of dissolution with a corresponding impoverishment of the microfauna and an increase in the percentage of benthonic foraminifera (mainly lagenids and simply structured arenaceous foraminifera). The dissolution affects mainly the large keeled Globorotalia, whereas the smaller "Acarinina" are more resistant. Therefore, these "dwarfed" planktonic foraminiferal faunas can probably be attributed to the effects of dissolution.

All five samples from Core 12 are interpreted to be early Eocene (Globorotalia formosa formosa Zone). The microfaunas are rich and well preserved and consist almost exclusively of planktonic foraminifera. Indications of dissolution in the planktonic foraminiferal tests are weak or absent.

The abrupt change in the composition of the planktonic foraminifera between Section 1 of Core 13 and the base of Core 12 suggests the absence of the lowermost zone of the early Eocene (Globorotalia subbotinae Zone).

Noteworthy is the occurrence of distorted Ramulininae in Sample 12-2, 18-20 cm. In the sample from Section 1 of Core 12, many specimens of Globorotalia formosa formosa become heavily ornamented, especially on the umbilical chamber tips, and are somewhat transitional to Globorotalia crater.

The earliest 'occurrence of Globorotalia pentacamerata in the core-catcher sample of Core 11 marks the base of the Globorotalia aragonensis Zone. The entire Core 11 is correlated to the upper part of the early Eocene (Globorotalia aragonensis Zone and Globorotalia pentacamerata Zone). As is often the case, the limit between these two zones is indistinct. It is placed 


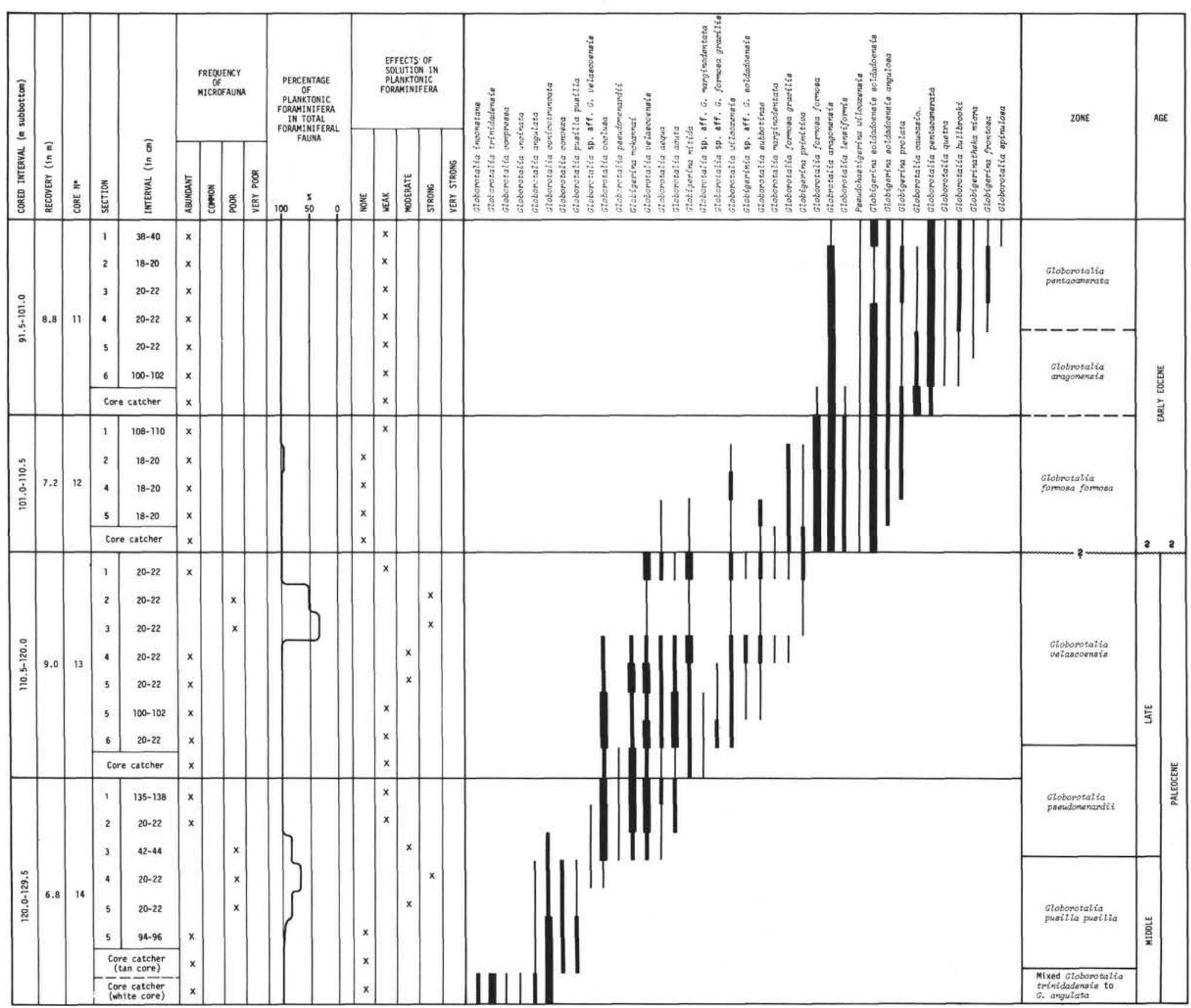

Figure 1. Distribution of selected planktonic foraminifera in Cores 11 to 14, Site 305. 


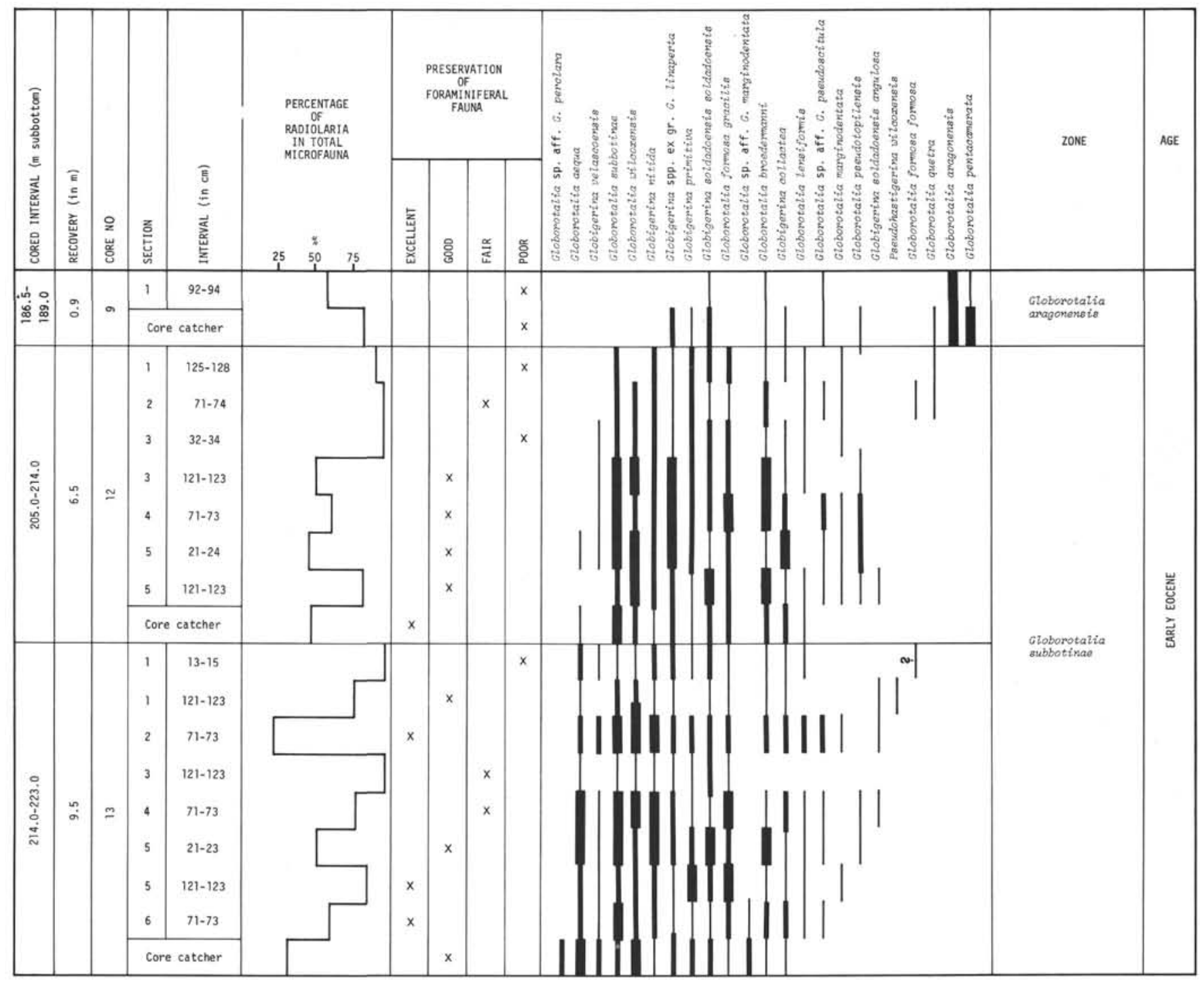

Figure 2. Distribution of planktonic foraminifera in Cores 9 to 13, Site 313.

between Samples 11-5, 20-22 cm and 11-4, 20-22 cm, based on the first occurrence of Globigerina frontosa. Globorotalia pentacamerata (= Globorotalia aspensis of authors) dominates the assemblages of the upper part of Core 11. All microfaunas of Core 11 are very rich and composed almost exclusively of planktonic foraminifera which show only weak traces of dissolution.

Core 10 is dated as middle Eocene (see Toumarkine, this volume).

\section{SITE 308-KŌKO GUYOT}

(lat $34^{\circ} 58.94^{\prime} \mathrm{N}$, long $172^{\circ} 08.98^{\prime} \mathrm{E}$, water depth $1331 \mathrm{~m}$ )

The shallow marine benthonic foraminifera from Site 308 are described by J. Ferrer (this volume). Planktonic foraminifera are very rare to rare in all samples. However, they occur in sufficient numbers to allow dating of Cores 1, 2, 3, and the top of Core 4. All samples are attributed to the early Eocene Globorotalia formosa formosa Zone. The core-catcher sample of Core 1 and Sample 2-2, 118-120 cm, contain Globorotalia formosa formosa, Globorotalia aragonensis, Globorotalia lensiformis, Globorotalia quetra, Globorotalia pseudotopilensis, Globigerina spp. ex gr. G. linaperta, Globigerina soldadoensis soldadoensis, Globigerina soldadoensis angulosa, and Pseudohastigerina wilcoxensis. Planktonic foraminifera are very scarce in Sample 3-1, $30-32 \mathrm{~cm}$, the core-catcher sample of Core 3, and Sample 4-1, 30-32 cm, but Globorotalia formosa formosa and Globorotalia aragonensis are still represented by a few specimens.

\section{SITE 313-NORTHEASTERN MID-PACIFIC MOUNTAINS} (lat $20^{\circ} 10.52^{\prime} \mathrm{N}$, long $170^{\circ} 57.15^{\prime} \mathrm{W}$, water depth $3484 \mathrm{~m}$ )

An attempt to core the Cretaceous-Tertiary boundary at Site 313 failed (see Site 313 chapter). Core 15 is Maestrichtian in age. A thin section made from the chert recovered in the core catcher of Core 14 contains a few ghosts of Radiolaria, sponge spicules, and a few tiny globigerinids and globorotaliids which are not sufficient for age determination. 
All samples from Cores 13 and 12 are attributed to the early Eocene (Globorotalia subbotinae Zone) (for distribution of species, preservation of microfaunas, and location of samples, see Figure 3). The planktonic foraminiferal assemblages are dominated by Globorotalia subbotinae, Globorotalia wilcoxensis, Globorotalia formosa gracilis, Globigerina nitida (= Acarinina acarinata), and Globigerina soldadoensis soldadoensis. Globorotalia aequa is restricted to Core 13 and the base of Core 12, whereas Globorotalia formosa formosa first appears in the upper part of Core 12. This may indicate that most of the interval corresponding to the Globorotalia subbotinae Zone is represented in Cores 13 and 12.

Almost all washed residues are composed of more than $50 \%$ Radiolaria. In general, the preservation of the planktonic foraminifera is better in samples with relatively few Radiolaria. Benthonic foraminifera are practically absent. A few samples contain reworked globo- truncanids. The planktonic foraminifera show only weak effects of dissolution.

No washed residues were obtained from Cores 11 and 10.

The two samples from Core 9 (only $36 \%$ of recovery) are poor and the planktonic foraminifera are badly preserved. Radiolaria dominate both samples. Core 9 is attributed to the early Eocene (Globorotalia aragonensis Zone) based on the co-occurrence of Globorotalia aragonensis and Globorotalia pentacamerata. A few specimens of Globorotalia aragonensis are transitional to Globorotalia caucasica.

\section{REFERENCE}

Stainforth, R. M., Lamb, J. L., Luterbacher, H., Beard, J. H., and Jeffords, R. M., in press. Cenozoic planktonic foraminiferal zonation and characteristics of index forms: Univ. Kansas, Paleontol. Contrib. 


\section{PLATE 1}

All figures $\times 75$; (a) spiral view; (b) umbilical view; (c) lateral view

Figures 1, 2 Globorotalia trinidadensis Bolli; 305-14, CC (lumps of white chalk).

Figure 3 Globorotalia praecursoria (Morozova); 305-14, $\mathrm{CC}$, (lumps of white chalk).

Figure 4 Globorotalia pseudomenardii Bolli; 305-14-2, 20-22 $\mathrm{cm}$.

Figure $5 \quad$ Globorotalia angulata (White); 305-14, CC, (lumps of white chalk).

Figures 6,7 Globorotalia conicotruncata Subbotina; 305-14, CC.

Figure $8 \quad$ Globorotalia velascoensis (Cushman); 305-14-1, $135-138 \mathrm{~cm}$. 
PLATE 1
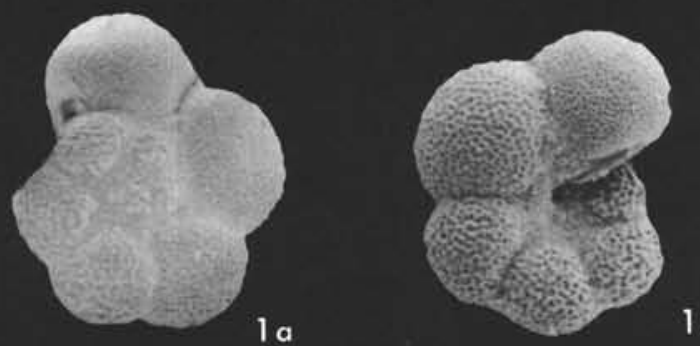

$1 \mathrm{~b}$
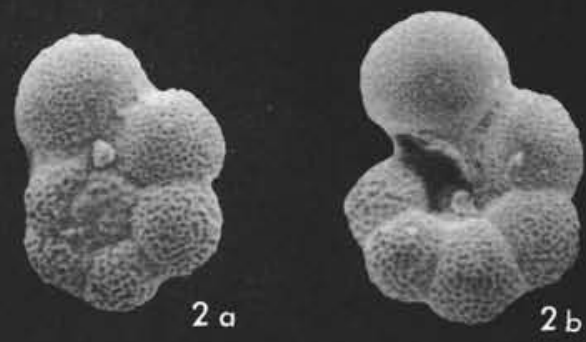

$3 a$
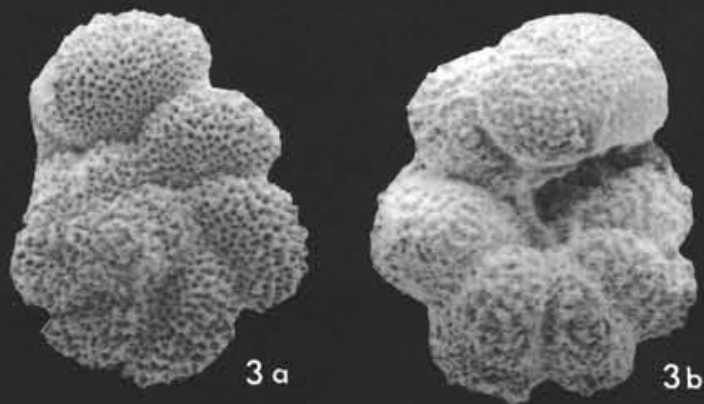
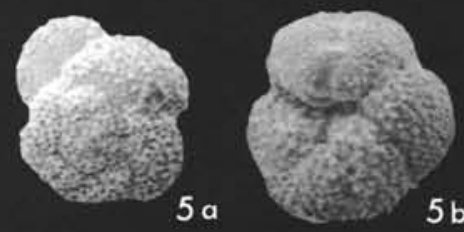
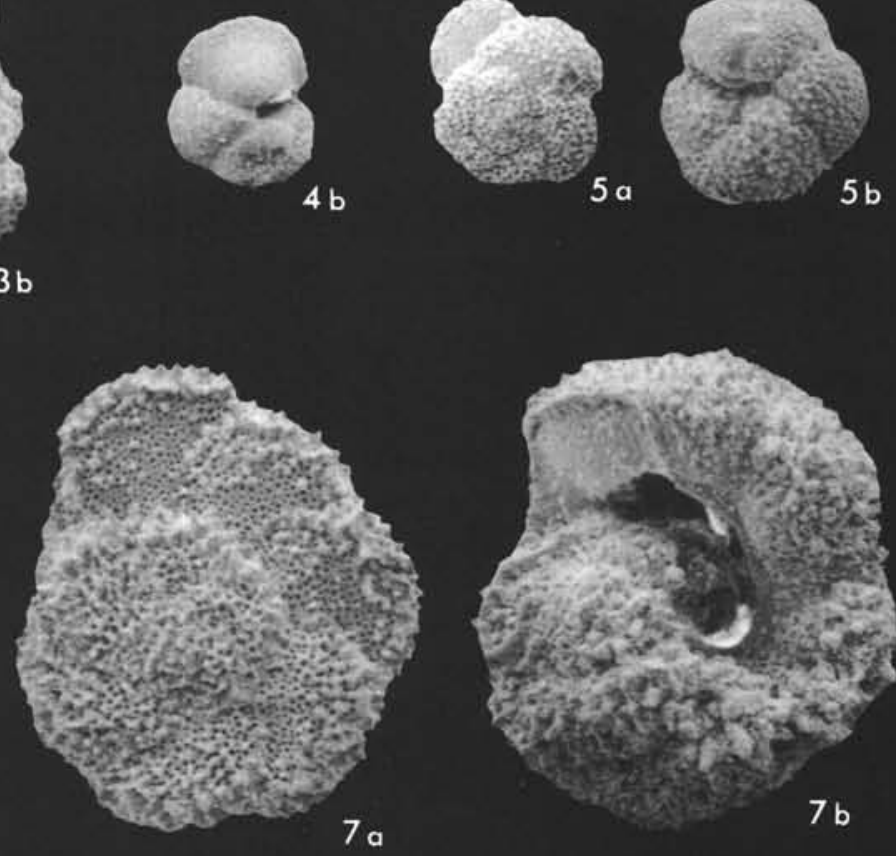
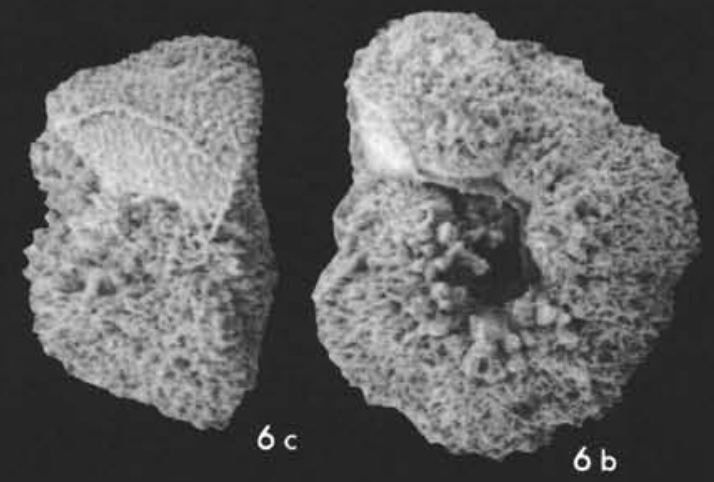

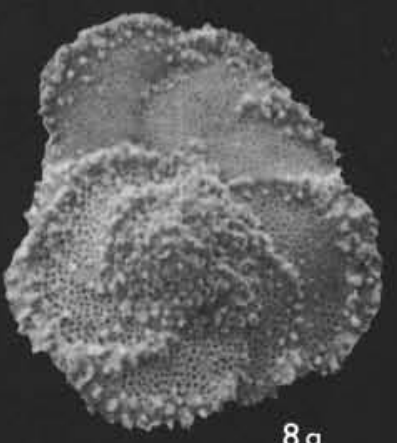

$8 a$

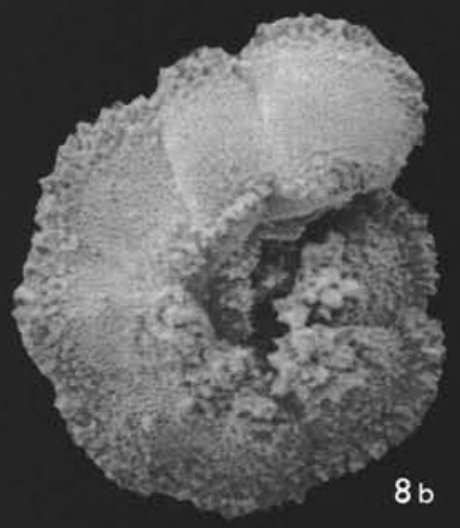




\section{PLATE 2}

All figures $\times 75$; (a) spiral view; (b) umbilical view; (c) lateral view.

Figure 1 Globigerina turgida Finlay; 305-12, CC.

Figure 2 Globorotalia subbotinae Morozova; 305-12, CC.

Figure 3 Globigerina primitiva Finlay; 305-12, CC.

Figure 4 Globigerina nitida Martin; 305-12, CC.

Figure $5 \quad$ Globorotalia aragonensis Nuttall; 305-11-2, 18-20 $\mathrm{cm}$.

Figure $6 \quad$ Globorotalia marginodentata Subbotina; 313-12-5, $121-123 \mathrm{~cm}$.

Figure $7 \quad$ Globorotalia formosa gracilis Bolli; 313-13-4, 71-73 $\mathrm{cm}$. 


\section{PLATE 2}

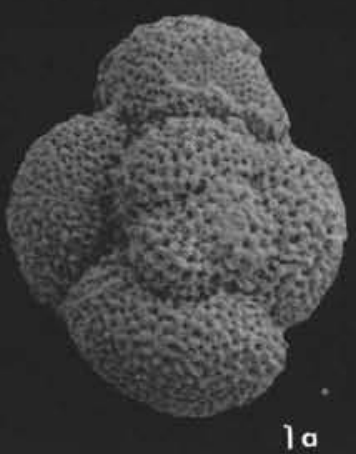

1a

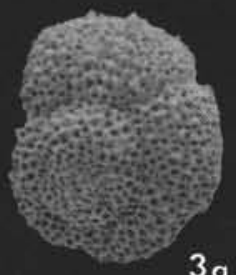

$3 a$
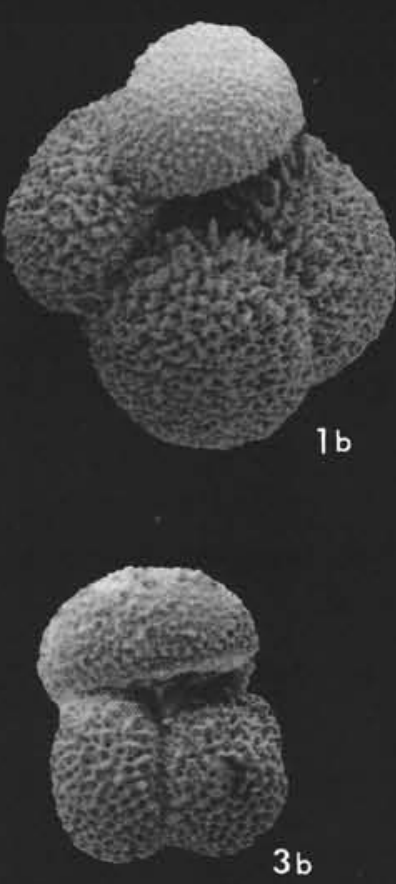
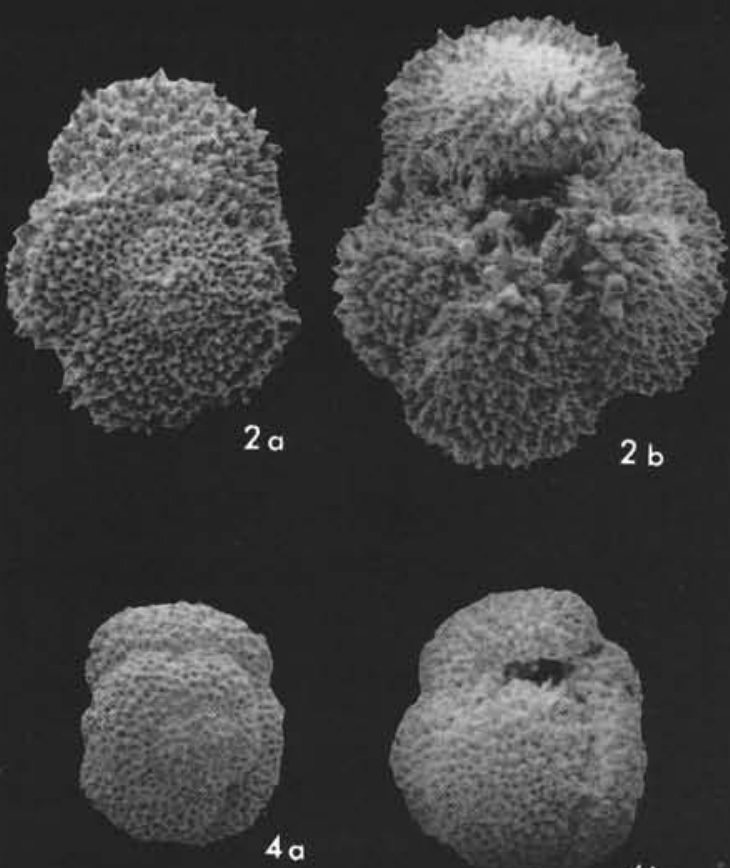

$4 \mathrm{~b}$
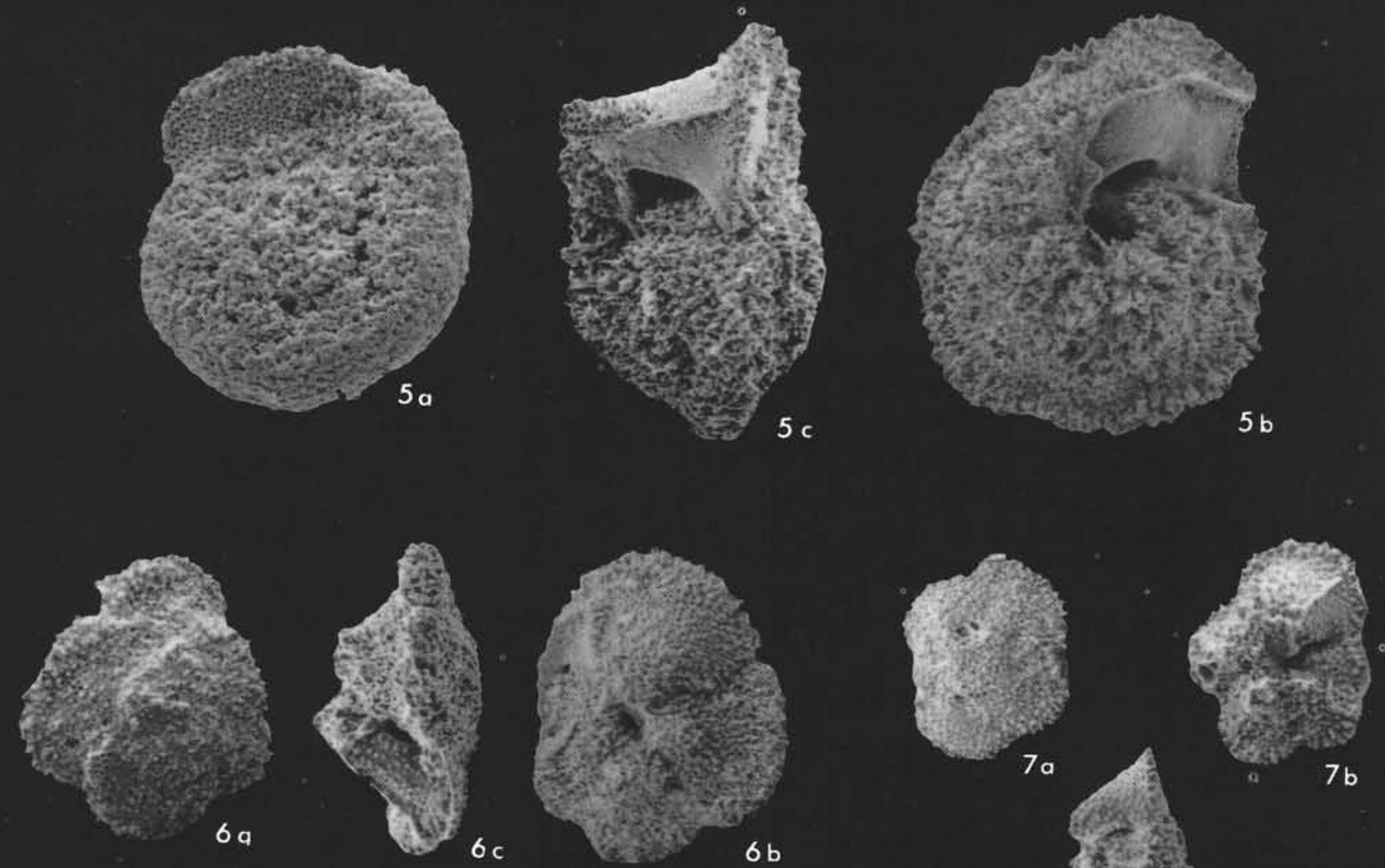

$6 b$ 